\title{
Visual Representation of Tourism Image in Short Video: Comparison between Agency-Generated Video and User-Generated Video
}

\author{
Wanlian Li*, Zhang Chen, Wenjie Guo \\ School of Business Administration, Anhui Finance and Economics University, Bengbu, Anhui, China \\ *liwanlian2003@163.com
}

\begin{abstract}
Short video has become one of the important tourism marketing media in the era of mobile internet. Taking Xixianan village, Huangshan City, Anhui Province as an example, this study selects one agency-generated video (AGV) and one usergenerated video (UGV) as research materials, and adopts content analysis method to analyze the content theme and structure difference of two videos on tourism image representation of Xixinan. It is found that differences exist in content structure of visual representation of tourism image of Xixinan between the two short videos. AGV focuses on the comprehensive representation of natural, cultural, folk and other attractive elements of Xixinan, while UGV lays emphasis on the representation of detailed elements such as tourist experience. When producing short videos, destination marketing organizations need to take into account the representation of tourist experience elements, and promote AGV and UGV to play their respective positive effects in tourism image promotion.
\end{abstract}

Keywords: Tourism short video, Visual representation, Tourism image, Content analysis, Xixinan.

\section{Introduction}

The importance of image in the tourism development of a place is reflected by the sustainable academic interest from 1970 's to the present. Tourist destination image was defined as the sum of tourists' cognition, beliefs, thoughts and impressions of a destination (Crompton, 1979) [1]. In theory, early research focused more on the definition, structure and measurement of destination image (Hunt,1975; Gartner,1989; Echtnerand Ritchie, 1991; Lai and Li, 2016) [2-5], and the follow-up research mainly focus on the internal and external influencing factors of the destination image and their interaction and formation process (Beerliand Martín, 2004; Grosspietsch, 2006; Alvarez and Campo, 2014; Kim and Chen, 2016; Prayag, et al., 2017) [6-10]. In practice, shaping a good destination image is an important way to attract tourists, and it is a very important marketing strategy for Destination Marketing Organization (DMO).Along with the development of modern science and technology, especially the internet has had a profound impact on the destination image, this influence has attracted great attention from tourism marketing organizations and tourism researchers(Cho, et al., 2002; Law, et al.,2014; Smith et al., 2015; Molinillo,et al.,2018) [11-14]. At present, with the rapid development of Web2.0 and mobile internet, both DMO and tourists can easily share the photos or videos of the destinations on travel websites or various social media platforms, which not only greatly increased the speed of destination image information, but also greatly enriched the transmission channels and carriers of destination image information. Various forms of visual media, such as travel photos, travel videos, and travel movies and television series have been widely used in tourism image promotion to show the actual situation of the destination attractions and services, to project the destination image to the potential tourists (Garrod, 2009) [15], and further to stimulate people's travelling interest and attract people's attention on the images or video objects, i.e. the tourism destinations.

The digital online dissemination of travel information makes it more convenient for tourists to obtain information of tourism destinations. Before choosing a destination, more and more tourists will watch various online travel photos or videos uploaded by enterprises, public institutions or other tourists, to get some information about the destination's tourist attractions, accommodations, facilities and services, among these visual media materials, travel videos provide potential tourists with effective sensory stimulation, provoke their imagination, and provide a virtual audiovisual sensory experience and communicate the travel information provided by professionals organization or other tourists (Chiou, etal., 2008; Vries, et al., 2012) [16-17]. Some research showed that tourism movies and videos can help not only to create good destination image (Alvarez and Campo, 2011) [18], and also to motivate the travel intention of the potential tourists (Kim, et al., 2018) [19], The video marketing of tourism image is becoming one of the most common DMO's marketing strategies.

On the one hand, DMO produced promotional videos to be published on various social networking sites, released the projected image of the tourist destination to the public, and realized the marketing goals of promoting the tourist image (Reinoand Hay, 2011; Lim, et al., 2012; LosadaandMota, 2019) [20-22]. On the other hand, the widespread use of social networking platforms has gradually broken the traditional travel information's media dissemination pattern. It has become more convenient than ever for users to share travel experiences, travel photos, and travel videos online. These visual materials are more than just objective image records, among them, the landscape, characters, events, etc. constitute the destination elements which most touched them in their travel experience. It is the carrier that expresses the tourists 'cognition and opinions on the destination, and can be regarded as the visualized "symbol" of the image of the destination. This kind of tourist destination image information created and disseminated by tourists plays a prominent role in 
portraying a unique destination image. At the same time, because it does not have commercial marketing intentions, it is more persuasive and influential for potential tourists than the visual content published by DMOs and travel middlemen, and the impact on the destination image is sometimes more than the marketing promotion launched by $\mathrm{DMO}(\mathrm{Connell}$, 2005) [23], to a certain extent, which has caused tourism operators to gradually lose the traditional initiative and control in the shaping of destination images, that is, the shaping and dissemination of destination images are gradually moving towards the cocreation by the DMO and tourists. The large number of online existence of the destination image caused by the tourists generating content has two kinds of effects on the destination image, one is positive, the other is negative, and the destination image generated by tourists is actually exceeded the direct control range of $\mathrm{DMO}$, and it is easily to cause the realistic management problems of DMO on the inconsistent between the DMO projection image and the tourists induced image. In order to better implement the destination image marketing management strategy, the DMO needs to know the difference between the induced images generated by tourists and the projected images generated by DMO.

Some researchers have noticed that there is a difference between the destination induced image and projected image, and have done some studies by using the user generated contents on the social media, such as travel photos, travel notes, blogs, and online reviews of tourists(Stepchenkova and Zhan, 2013) [24], among these studies, it is increasing to use tourism visual materials as research objects. These studies are mostly focused on: (1) the visual representation's content analysis of the tourist destination image generated by professional agency or by tourists; (2) the potential tourists destination image perception caused by quality variables such as the shooting and production of tourist pictures or videos, and it's impacts of their travel intention; (3) the impact of watching travel videos on potential tourists' destination image perception and behavior intention. However, the existing research on the visual representation of the destination image is mainly based on static travel visual materials, such as tourism promotional pictures and travel photos, and there are few research based on the travel video, especially on the travel video from different generated sources, and there is less comparative research on the content analysis of destination image visual representation. In this study, an ancient Village named Xixinan, which located in Huangshan City, Anhui Province was chose as the empirical sites, and also two videos (agency-generated video,AGV) and a user-generated video,UGV) were selected as the research materials, a comparative study of the two short videos was employed on the destination visual image's content theme and structure, the differences of the destination image's attributes were analyzed between the induced image and the project image.

The significance of this study is as the followings: (1) In theory, this study focuses on the content analysis of the visual representation of tourism destination video, which promotes the visual representation of tourism image from the study of paper materials to the video materials. At the same time, the traditional research of tourism dynamic visual materials is mainly based on the perception survey after watching tourism film and television series, propaganda videos. This research analyzes the content of tourism short videos which expands the research vision of the dynamic visual image representation of tourism destinations; (2)In practice, the comparative analysis of the content theme and structure of the destinations video image's visual representation from different generated sources will help DMO to understand the tourists' actual perception of the destination image, and make the destination projection image positioning more in line with the real interest and experience of tourists. At the same time, the research will also help DMO to get more accurately understanding the different short videos' effectiveness on the construction of tourist destination images, and provide guidance for DMO to optimize the content production of tourism marketing videos.

\section{Literature Review}

The concept of tourism destination image was put forward in 1970s. Hunt (1975) [2] believed that tourism image is the perception of a region by potential tourists, Crompton (1979) [1] considered that tourism image is the sum of belief, concept and impression held by a person to a destination, Gartner (1989) [3] regarded tourism image as a complex combination of various products and related attributes of a tourist destination, and Echtner and Ritchie (1991)[4]defined tourism image as tourists' perception of the specific attributes of the destination and the impression of the overall image.Gallarza, et al. (2002) [25] suggest that destionation image is a complex, relative, multiple, and dynamic concept. More recently, Lai and $\mathrm{Li}$ (2016)[5]have defined tourist destination image as "a voluntary, multisensory, primarily picturelike, qualia-arousing, conscious, and quasi-perceptual mental (i.e., private, non-spatial, and intentional) experience held by tourists about a destination".Baloglu and McCleary (1999)[26]present a destination image model based on two dimensions (i.e., cognitive image and affective image) that together result in an overall image, the model has been validated by a significant number of tourism studies in different cultural environments (e.g., Kim and Richardson, 2003; Smith, et al., 2015) [27,13]. There also had some study focuses on cognitive destination images because they are directly observable, descriptive, and measurable (Walmsley and Young, 1998) [28], and they can provide more concrete and interpretive information regarding the uniqueness of a destination (Prayag and Ryan, 2012; Veasna,et al., 2013)[2930]. These previous studies used a list of destination attributes to assess image perceptions. Totally, the concept of tourism image especially emphasizes the perception of tourists, which is related to their attitude towards the destination, and then affects the overall concept of liking or disliking the destination (Ahmed, 1991) [31]. Before tourists visit a certain tourist destination, due to the invisibility of the destination products and the limited destination knowledge of tourists themselves, the perception of the destination image will affect tourists' decision-making and tourism behavior intention (Echtner and Ritchie, 1991;Balogluand McCleary, 1999)[4,26], and tourist is more likely to consider and select destinations with strong positive images in the process of travel decision-making (Woodside andLysonski, 1989; Choi, et al., 2011)[32-33]. Meanwhile, tourists' image perception also affects their satisfaction with destination attribute experience (Chi and $\mathrm{Qu}, 2008$ ) [34] and their future revisiting behavior and recommendation behavior (Prayag, et al., 2017) [10]. Therefore, the creation and dissemination of tourism image has always been the focus of academic research and marketing management of DMO.

The study of visual representation of tourism image begins with studies of tourism postcards (YükselandAkgül, 2007) 
[35], photos (Jenkins, 2003; Pan et al.,2014) [36-37], etc. Some researches focused on travel photos shared by tourists, for instance, Pearce et al. (2015) [38] who studied the photos of the Great Ocean Road, Australian iconic landscape, taken by Chinese tourists, found that these photos focused on the representation of two types of attractions, one is the spectacular natural environment characteristics, the other is multiple small-scale, ordinary sites and places. Sun et al. (2014) [39], through the analysis of blog photos of Chinese tourists visiting New Zealand, found that there are ten themes of New Zealand tourism destination images, among which New Zealand brand image based on natural landscape has the greatest impact. Other studies focus on the comparative study of photos released by DMO and tourists. For example, the study of Jenkins (2003) [36] showed that there is a part of cultural "circular representation" between the photos published in the tourist brochure by Australian tourism marketing organization and the photos taken by backpackers during the journey, which are mostly the iconic tourist attractions of Australia. The study of Stepchenkova and Zhan (2013) [24] extracted 10 destination image categories from the photos of DMO projection image and Flickr perception image in Peru, and compared the representations of various regions in Peru. The study results partially supported the viewpoint of circular representation of destinations. Michaelidou et al. (2013) [40] compared the photos published on the Internet by tourists and tourism enterprises, and found that there was a difference between the overall image of Taiwan tourism perceived by tourists and the image created by tourism enterprises. The study of travel photos of Arabia countries on Flickr by Syed-Ahmad et al. (2013) [41] also found that the image of the destination that caused the majority of viewers to respond to was different from the image represented in official travel and tourism documents.

With the rapid development of the Internet, the search of tourist information is becoming more and more convenient for tourists. Before choosing a destination, tourists will watch various kinds of videos online to understand the tourist attractions, facilities and services of the destination. The change of information search behavior of tourists promotes DMO to pay more and more attention to the use of tourism videos to promote and advertise the destination image. Researches on tourism videos in the academic community were recognized in some extent (Kim, et al., 2018; Reinoand hay, 2011) [19-20]. In the study of visual representation of tourism video, the study by Shani et al. (2010) [42] showed that the representation of China's tourism promotional video on the national tourism image is mixed and contradictory, and there are polarization characteristics of the representation of modernization, nature and history. The study on the relationship between the effect of New Zealand Tourism TV advertisement and the formation of destination image by Pan (2011) [43] found that the content elements that need to be considered in the production of promotional tourism video include the familiarity of the audience, color, interpersonal interaction and the interaction between people and the environment, and these elements are directly proportional to the desire of the audience to visit the destination. Cheng et al. (2015) [44] analyzed, compared and evaluated the commentary text and image visual representation of tourism image videos of two Jiangnan ancient towns in China, Tongli and Nanxun. The results showed that there was similar representation content structure in the tourism image videos of the two ancient towns. Six categories of representation
Contents, natural resources, ecological environment, culture and art, social environment, tourism infrastructure, tourism, leisure and entertainment, constitute the core content of the two short videos. The study by Losada and Mota (2019) [22] found that the representation of the marketing promotional short video of the slow tourism destination Douro Region is lack of a clear key element which helps to improve the region's ability to become a slow tourism destination. In terms of the impact of tourism video on audience perception and behavior intention, the study by Lim et al. (2012) [21] found that compared with the video generated by destination marketers, the video generated by consumers has a smaller positive impact on destination brands. The study by Hautz et al. (2014) [45] found that use-generated video (UGV) has no more advantages than agency-generated video (AGV) in terms of the impact on audience perception and behavior intention, and UGV has a greater positive impact on consumers' expected behavior in terms of the credibility and professionalism of information sources when the quality of video technology is low. Alamäki et al. (2019) [46] designed three types of natural tourist destination mobile marketing videos (instructive, seductive and decorative video) to measure the triggering effect on participants' behavioral intentions. The results showed that among the three types of videos, instructional designed videos are more likely to trigger the emotional trigger effect of the audience, that is, the more participants like the video, the greater the impact on their willingness to participate and the recall after watching.

In conclusion, it can be noticed that tourism video marketing in the destination can not only stimulate the audience's imagination of the destination, create a good destination image, but also improve the audience's travel intention. However, in the network era, tourism videos from different sources have different interpretations of the destination image. DMO needs to understand the similarities and differences of the visual representation of AGV and UGV, so as to more effectively implement the destination tourism video marketing management.

\section{Research Materials and Research Methods}

\subsection{Brief Introduction of Xixinan Village}

Xixinan ancient village is located in Huizhou District, Huangshan City, Anhui Province, with beautiful natural ecological environment and profound Huizhou cultural heritage. The ancient village has a history of 1200 years, which is an emerging tourist destination integrating sightseeing and vacation functions. At present, the village still retains the famous water conservancy cultural heritage, Huizhou architectural cultural heritage, unique village culture, culture of rubbing from stone inscription, Hui business culture, as well multiple famous ancient trees and the best preserved natural wetland pterocarya forest in southern Anhui. Compared with Huangshan, Xidi, Hongcun and other famous tourist destinations in southern Anhui, the tourism development of Xixinan started relatively late, and the village has only become famous in the tourism market in recent years, so it's market popularity is not high. Xixinan village was selected as the destination for empirical research site can avoided the biases in the perceived image due to the audience's prior knowledge of the destination. 


\section{2. . Short Video Materials}

The selection of research video materials follows the following standards: first, the selected video can fully demonstrate the current situation and panorama of tourism attractions in Xixinan; second, the two videos are similar in length. By searching for "Xixianan" on mainstream video websites such as Tencent video, Youku video, Iqiyi, etc., play videos one by one for viewing and screening, and finally select and download two short videos as research materials. To ensure that the two videos are similar in length, researchers edit the information about the video producers at the beginning and end of the two videos out, without editing the main content of the videos. See Table 1 for the basic information of the two video materials after editing.

Table 1. Basic Information of Video Materials

\begin{tabular}{|c|c|c|}
\hline Video type & Video material name and source & $\begin{array}{c}\text { Length after } \\
\text { editing }\end{array}$ \\
\hline $\begin{array}{l}\text { Agency-generated } \\
\text { video }(A G V)\end{array}$ & $\begin{array}{l}\text { Beautiful Village in Anhui: National version of the Wizard of Oz: Xixinan, a hidden ancient } \\
\text { village in Huizhou (release date: March 22, 2019) } \\
\text { Producer: "Beautiful Village in Anhui", Anhui Tourism, "100 Villages", Marketing Activity, "100 } \\
\text { Villages Shooting" activity sponsored by Anhui Provincial Tourism Development Committee and } \\
\text { co-organized by Anhui Broadcasting Corporation. Video website: } \\
\text { https://v.qq.com/x/page/x0852ohp8cv.html }\end{array}$ & $02: 11$ \\
\hline $\begin{array}{l}\text { User-generated } \\
\text { video (UGV) }\end{array}$ & $\begin{array}{l}\text { Slow Travel in Ancient Village Xixinan in Autumn (release date: November 12, 2018) } \\
\text { Producer: Little dreams of pigsty Video website: } \mathrm{https} / / \mathrm{v} . q \mathrm{q} . \mathrm{com} / \mathrm{x} / \text { page/u079087q13g.html }\end{array}$ & $02: 23$ \\
\hline
\end{tabular}

\subsection{Research Method}

This study mainly adopts content analysis method to carry out the research. The steps of the research mainly refer to the research of Cheng, et al. (2015) [44], specifically including: (1) video material preprocessing. The software PotPlayer is used to take screenshots of video frames, taking one second as the unit of time. Take 131 and 143 pictures from AGV and UGV respectively and keep 38 and 60 pictures respectively after removing highly similar pictures. Meanwhile, the commentary or subtitles in the video are recorded word by word and organized into Word documents. The preprocessed pictures and Word documents are input into NVivo11.0 software and used as the basic material of content analysis. (2) classification and coding. One graduate and one professional teacher conduct multi-dimensional content analysis of people, objects and environment elements presented in screenshots, commentaries and subtitles, carry out the open initial coding (free node) for the content elements in $\mathrm{AGV}$ and $\mathrm{UGV}$ respectively, so that their category gradually show up in the data, and classify and name (tree node) each initial coding (free node) to create focused coding, and finally, extract the tree node to form the content component dimension of evaluable and describable video representation elements, which is named as theoretical coding. If there are differences in the coding process, the two coders will discuss until a consensus is reached to ensure the reliability and validity of the content analysis materials. (3) coding reliability test. In order to ensure the category reliability of coding categories, the classification of node categories in the coding process mainly refers to the classification and naming methods of node categories inCheng et al. (2015) [44],Stepchenkova and Zhan (2013) [24]'s research. Specially several individual elements that appear in the two videos, and there were no ready-made coding categories in existing references, the coding team worked together to discuss until an agreement was reached, in this research, the specific notes will be individually coded as a free node and directly included in the category of tree nodes.

At the same time, the Holsti inter-reterreliability(Holsti, 1969) [47] method was used to calculate the reliability (R) to ensure the inter-judge reliability between encoders. The calculation formula is:

$$
\mathrm{R}=(\mathrm{n} \times \mathrm{k}) /(1+(\mathrm{n}-1) \mathrm{k})
$$

In formula (1), $\mathrm{R}$ is the reliability of content analysis, $\mathrm{n}$ is the number of coders, $\mathrm{k}$ is the average mutual agreement of coders, and the calculation formula of $\mathrm{k}$ is as follows:

$$
\mathrm{k}=(\mathrm{n} \times \mathrm{M}) /\left(\mathrm{N}_{1}+\mathrm{N}_{2}\right)
$$

In formula (2), $\mathrm{M}$ represents the number of codes that the two coders agree on, and $\mathrm{N}_{1}$ and $\mathrm{N}_{2}$ respectively represent the total number of codes analyzed by the two coders.

In this study, the total number of codes analyzed by the two coders $\mathrm{N}_{1}$ is $70, \mathrm{~N}_{2}$ is 74 , and the number of codes $\mathrm{M}$ completely agreed by the two coders is 63 . According to formula (2), the mutual agreement $\mathrm{k}$ between the two coders is 0.875 , and the number of people participating in the coding is 2 . According to formula (1), the coding reliability $\mathrm{R}$ is 0.9333 , which is higher than 0.81 , according to Holsti(1969) [47] and Stemler (2001) [48], Kappa Statistic between 0.81 to 1.00 , it means the strength of agreement is almost perfect, so the two coder's judgment results on the same category are highly consistent and the coding result is credible. For the inconsistent coding that occurred during the coding process, the two coders discussed until they reached a consensus, and then formed the final 70 free nodes.

\section{Findings}

\subsection{Coding and Node Categories of Short Video Screenshots}

NVivo 11.0 software is used to encode the two short video screenshots initially, that is, to extract the free nodes, and classify the free nodes of similar elements to form a tree node, that is, focused coding. Then, the categories of tree nodes are merged for theoretical coding. Finally, the two videos create 70 initial coding (free nodes), 14 focused coding (tree nodes) and 5 theoretical coding (Table 2). Among them, 14 tree node categories are: panorama of ancient village, idyllic scenery of ancient village, river systems inside and outside village, people, residential buildings of ancient village, development and protection of ancient village, historic culture of ancient 
Table 2. Description of Node Categories.

\begin{tabular}{|c|c|c|c|}
\hline $\begin{array}{l}\text { Theoretical } \\
\text { coding }\end{array}$ & $\begin{array}{l}\text { Focused coding } \\
\text { (tree node) }\end{array}$ & Initial coding (free node) & Reference point description \\
\hline \multirow{2}{*}{$\begin{array}{l}\text { Ecological } \\
\text { environment }\end{array}$} & $\begin{array}{l}\text { Panorama of } \\
\text { ancient village }\end{array}$ & 1. Panorama of ancient village & Aerial panorama of ancient village \\
\hline & $\begin{array}{l}\text { Residential } \\
\text { buildings of } \\
\text { ancient village }\end{array}$ & $\begin{array}{l}\text { 1. Courtyard landscape and decoration; } 2 \text {. Huizhou } \\
\text { ancient residence houses; } 3 \text {. Newly-built Huizhou } \\
\text { residence houses; } 4 \text {. Ma Tau Wall of Huizhou } \\
\text { buildings; } 5 \text {. Mottled exterior wall of ancient } \\
\text { residence houses; } 6 \text {. Indoor layout of ancient } \\
\text { residence houses; } 7 \text {. Ancient residence houses with } \\
\text { wood structure; } 8 \text {. Patio of ancient residence } \\
\text { houses; } 9 \text {. Brick carving; } 10 \text {. Stone carving; } 11 \text {. }\end{array}$ & $\begin{array}{l}\text { The whole and partial Huizhou ancient } \\
\text { residence houses }\end{array}$ \\
\hline \multirow[t]{4}{*}{$\begin{array}{l}\text { Historic } \\
\text { culture }\end{array}$} & $\begin{array}{l}\text { Characteristic } \\
\text { landscape } \\
\text { elements of public } \\
\text { space of ancient } \\
\text { village }\end{array}$ & $\begin{array}{l}\text { Wood carving } \\
\text { 1. Pond; 2. Pavilion; } 3 \text {. Stone slab bridge at the } \\
\text { entrance of the village; } 4 \text {. Bamboo bridge on the } \\
\text { river beside the village; } 5 \text {. Lanes in the ancient } \\
\text { village; } 6 \text {. Small stone bridge; } 7 \text {. Mossy stone in the } \\
\text { forest; } 8 \text {. Green stone bench }\end{array}$ & $\begin{array}{l}\text { Characteristic landscape sketch of public } \\
\text { space in ancient villages }\end{array}$ \\
\hline & $\begin{array}{l}\text { Historic culture of } \\
\text { ancient village }\end{array}$ & 1. Historic culture; 2 . Historical figures & $\begin{array}{l}\text { Historic culture of ancient village and } \\
\text { stories of historical figures }\end{array}$ \\
\hline & Beekeeping & 1. Honey gathering tool; 2 . Beehive & $\begin{array}{l}\text { Beekeeping and honey gathering is a } \\
\text { unique production mode of local people }\end{array}$ \\
\hline & Plants & $\begin{array}{l}\text { 1. Famous ancient trees; } 2 \text {. Pterocarya tree / } \\
\text { Pterocarya forest; } 3 \text {. Garden plants; } 4 \text {. Unknown } \\
\text { flowers and plants; } 5 \text {. Rape flowers; } 6 \text {. Lotus; } 7 \text {. } \\
\text { Osmanthus; } 8 \text {. Persimmon; 9. Parthenocissus } \\
\text { tricuspidata; } 10 \text {. Unknown trees }\end{array}$ & $\begin{array}{c}\text { The unique towering trees, famous ancient } \\
\text { trees, characteristic Pterocarya forest, } \\
\text { various garden plants and wild plants in the } \\
\text { ancient village }\end{array}$ \\
\hline \multirow[t]{3}{*}{$\begin{array}{l}\text { Natural } \\
\text { scenery }\end{array}$} & Animals & $\begin{array}{l}\text { 1. Bee; 2. Flying bird; 3. Goldfish; 4. Crested } \\
\text { myna; 5. Lazy cat }\end{array}$ & $\begin{array}{c}\text { Beekeeping and honey gethering are the } \\
\text { local characteristic production modes. } \\
\text { Flying birds in the pterocarya forest form } \\
\text { the characteristic landscape. Goldfish, } \\
\text { created myna and cat are the characteristics } \\
\text { of homestay }\end{array}$ \\
\hline & Natural scenery & $\begin{array}{l}\text { 1. Blue sky and white cloud; } 2 \text {. Distant mountain; } \\
\text { 3. Sunshine; } 4 \text {. Sunset; } 5 \text {. Misty rain }\end{array}$ & $\begin{array}{c}\text { Important natural landscape resources of } \\
\text { ancient village }\end{array}$ \\
\hline & $\begin{array}{l}\text { Tourism reception } \\
\text { support system }\end{array}$ & $\begin{array}{l}\text { 1. Featured homestay; } 2 \text {. Featured food; } 3 \text {. Tourism } \\
\text { logo; } 4 \text {. External transportation; } 5 \text {. Internal and } \\
\text { external roads of ancient village; } 6 \text {. Rural pleasures; } \\
\text { 7. Panoramic view of surrounding homestay cluster } \\
\text { area }\end{array}$ & $\begin{array}{l}\text { Food, housing, transportation, tourism and } \\
\text { other related elements related to tourism } \\
\text { service facilities and tourism infrastructure, } \\
\text { among which, the coding elements of } \\
\text { featured homestay involve the followings } \\
\text { of the room of featured homestay: (1) floor } \\
\text { glass window; (2) glass skylight; (3) } \\
\text { featured room decorations; (4) featured } \\
\text { furniture; (5) bed; (6) toilet; (7) indoor } \\
\text { decorative plants; the external } \\
\text { transportation mainly includes: (1) high- } \\
\text { speed rail; (2) coach }\end{array}$ \\
\hline $\begin{array}{l}\text { Tourism } \\
\text { infrastructure }\end{array}$ & $\begin{array}{l}\text { Unique } \\
\text { experience of } \\
\text { tourists }\end{array}$ & $\begin{array}{l}\text { 1. Tourists celebrate birthdays in the homestay; } 2 . \\
\text { Tourists taste Huangshan tribute chrysanthemumare } \\
\text { in the homestay; } 3 \text {. Tourists experience human and } \\
\text { cat interaction in the homestay }\end{array}$ & The experience of tourists in homestay \\
\hline \multirow{2}{*}{$\begin{array}{l}\text { Coordination } \\
\text { between } \\
\text { ancient village } \\
\text { and natural } \\
\text { ecological } \\
\text { environment }\end{array}$} & $\begin{array}{l}\text { Idyllic scenery of } \\
\text { ancient village }\end{array}$ & 1. Idyllic scenery of ancient village & $\begin{array}{l}\text { Take aerial photos of the idyllic scenery } \\
\text { surrounding the ancient village and the } \\
\text { idyllic scenery visible outside the window } \\
\text { of the homestay }\end{array}$ \\
\hline & $\begin{array}{l}\text { River system } \\
\text { inside and outside } \\
\text { the village }\end{array}$ & $\begin{array}{l}\text { 1. River beside the village; } 2 \text {. River entering the } \\
\text { village; } 3 \text {. River outside the village; } 4 \text {. Flood land }\end{array}$ & $\begin{array}{c}\text { The developed water conservancy system } \\
\text { of ancient village }\end{array}$ \\
\hline People & & $\begin{array}{c}\text { 1. Tourists; } 2 \text {. Village residents; } 3 \text {. Beekeepers; } 4 . \\
\text { Teachers and students of the seminar; } 5 \text {. } \\
\text { Participants of the seminar; } 6 \text {. Village protection } \\
\text { professionals }\end{array}$ & $\begin{array}{c}\text { Participants in the theme meeting and } \\
\text { seminar on the development and protection } \\
\text { of tourists, local residents and ancient } \\
\text { village featured buildings }\end{array}$ \\
\hline $\begin{array}{l}\text { Development } \\
\text { and protection } \\
\text { of ancient } \\
\text { village }\end{array}$ & & $\begin{array}{c}\text { 1. Promotion and display of historic culture; } 2 . \\
\text { Theme seminar; } 3 \text {. Development and protection } \\
\text { field survey; } 4 \text {. Rural tourism development; } 5 \text {. } \\
\text { Creative town }\end{array}$ & $\begin{array}{l}\text { Exhibitions, activities and events related to } \\
\text { the development of ancient village tourism, } \\
\text { the protection of historic culture and } \\
\text { characteristic ancient residence houses }\end{array}$ \\
\hline
\end{tabular}


village, tourism reception support system, characteristic landscape elements of ancient village, plants, animals, natural scenery, beekeeping and unique experience of tourists; 5 theoretical coding are: ecological environment, historic culture, natural scenery, tourism infrastructure, coordination between ancient village and natural ecological environment.

\subsection{Comparative Analysis of Node Categories of AGV and UGV}

After screenshots coding of the two short videos, the frequency of two groups of picture nodes is counted with NVivo11.0 software, as shown in Table 3. In general, the frequency of occurrence of plants $(16.67 \%)$, ancient village residential buildings $(14.39 \%)$, characteristic landscape elements of public space of ancient village (11.36\%) and people $(11.36 \%)$ in the representation content elements of AGV video of Xixinan is the top three. For tourism to Xixinan, tall and lush forest at the village entrance, unique pterocarya forest and characteristic landscape elements of some public space of ancient village public space, such as lanes, ponds, etc., all create unique tourist space and atmosphere for tourists the people node category represented by video mainly involves tourists, local residents and professionals who participate in the development and protection of ancient village. Among the representation content elements of UGV video of in Xixinan, the node categories of tourism reception support system $(28.68 \%)$, ancient village residential buildings $(26.36 \%)$ and natural scenery $(12.40 \%)$ rank in the top three in the video in terms of frequency of occurrence. UGV focuses on the content elements experienced by tourists such as featured homestay and special gourmet, and the representation of ancient village residential buildings and natural scenery is also relatively sufficient, which is a circular representation characteristic of content between UGV and AGV.

Table 3. Frequency and Percentage of Tree Node Categories.

\begin{tabular}{|c|c|c|c|c|}
\hline \multirow{2}{*}{ Tree node } & \multicolumn{2}{|c|}{$\mathrm{AGV}$} & \multicolumn{2}{|c|}{ UGV } \\
\hline & Frequency & Percentage $(\%)$ & Frequency & Percentage $(\%)$ \\
\hline Panorama of ancient village & 4 & 3.03 & 3 & 2.33 \\
\hline Ancient village residential buildings & 19 & 14.39 & 34 & 26.36 \\
\hline $\begin{array}{c}\text { Characteristic landscape elements of } \\
\text { ancient village }\end{array}$ & 15 & 11.36 & 6 & 4.65 \\
\hline Historic culture of ancient village & 4 & 3.03 & 1 & 0.78 \\
\hline Hometown of honey in China & 3 & 2.27 & 0 & 0.00 \\
\hline Plant & 22 & 16.67 & 12 & 9.30 \\
\hline Animal & 4 & 3.03 & 4 & 3.10 \\
\hline Natural scenery & 13 & 9.85 & 16 & 12.40 \\
\hline Tourism reception support system & 9 & 6.82 & 37 & 28.68 \\
\hline Unique experience of tourists & 0 & 0.00 & 3 & 2.33 \\
\hline Idyllic scenery of ancient village & 6 & 4.55 & 7 & 5.43 \\
\hline River system inside and outside the village & 7 & 5.30 & 0 & 0.00 \\
\hline People & 15 & 11.36 & 5 & 3.88 \\
\hline $\begin{array}{l}\text { Development and protection of ancient } \\
\text { village }\end{array}$ & 11 & 8.33 & 1 & 0.78 \\
\hline
\end{tabular}

In addition to being similar to most of the tourism image promos and taking the core or symbolic attraction of the destination as the main representation object, AGV video has taken the pictures of the special seminars related to the protection of ancient villages held in Xixinan village and field visits of relevant people. Therefore, when coding this part of content of AGV, a new tree node category that has not appeared in the existing literature has been raised, that is, "Development and Protection of Ancient Village". In UGV, most of the shooting time focuses on the characteristics, style and tourist accommodation experience of the homestay. For instance, tourists can enjoy the beautiful idyllic scenery, taste special food, experience the interaction between people and cats, and celebrate birthdays in the room of homestay. Therefore, when coding this part of content of UGV, it is named as the tree node of "Unique Experience of Tourists".

\section{Conclusion and Discussion}

\subsection{Conclusion}

Through the content analysis of the representation of Xixinan tourism image video, it can be seen that the visual representation of the content elements of Xixinan tourism image by $\mathrm{AGV}$ and $\mathrm{UGV}$ has similarities as well as differences. Such feature is also reflected in the comparative study of "User-generated images, official tourist brochures and travel guides" by Agustí et al. (2018) [49]. The concrete manifestation is as follows:

(1) Similarities in visual representation of tourism image elements between AGV and UGV. The similarities in visual representation of contents elements of Xixinan tourism image between AGV and UGV lies in that they both highlight the representation of Huizhou architecture in the ancient village and the regional characteristics and historic culture it carries. Huizhou culture and its carrier Huizhou architecture have always been the core attraction for the development of rural tourism in the ancient village in southern Anhui. The core motivation for tourists to visit the ancient village in southern Anhui is to visit the ancient village and understand the Huizhou culture, Therefore, both videos pay great attention to the representation of the historic cultural elements of the Xixinan ancient village.

(2) Differences in visual representation of tourism image elements between AGV and UGV. There are differences in the visual representation of the content elements of Xixinan tourism image between AGV and UGV. Specifically, AGV pays more attention to the representation of the core attraction of the destination (Xixinan village ancient residence houses, pterocarya forest beside the village), while UGV lays more emphasis on the representation of tourist experience. For 
example, the picture of livelihood activities of villagers' beekeeping and special seminars on the development and protection of ancient villages only appears in AGV, while the physical experience pictures of the facilities, food, tea and other elements of the homestay are only appeared in UGV. These differences are largely affected by the shooting conditions and shooting perspective possessed by the video production subject. AGV is produced by a professional team, which can get the support of the local tourism management department and be more familiar with the overall situation of the tourism resources and attractions of the destination. On the other hand, UGV is generally shot by tourists when they travel to the destination. Due to the fact that some of the special folk activities in the tourism destination may be affected by seasons, weather and other external conditions, there are situations that these activities can't all be experienced in one single visit. Therefore, some elements represented in AGV may not be represented in $\mathrm{UGV}$, on the contrary, some elements represented in UGV may not be represented in $\mathrm{AGV}$.

\subsection{Managerial Implications}

In the era of diversified, fragmented and audio-visual network, short video has opened up a new mode of tourism product marketing. The tourism video released by tourists on the network has objectively formed second communication of destination image (Deng, et al., 2019) [50], which has become an important part of video marketing in tourism destinations together with the video produced and released by DMO (Reinoand Hay, 2011) [20]. DMO still has many problems worthy of further discussion in the process of short video tourism marketing management. Combined with the results of this study, the following marketing management suggestions are proposed. First of all, DMO should pay attention to the guiding role of AGV in tourism image communication. This study shows that AGV has obvious advantages in destination image representation because it can transmit more abundant tourism information to the audience. Therefore, DMO should pay attention to the guiding role of AGV video in the overall image communication of the destination when developing video marketing strategy. After all, tourism is a feast of visual experience, and experiencing beautiful natural scenery and profound cultural heritage is an important travel motivation of tourists. As the professional team has professional photography technology and content selection ability in the video production process, the produced tourism video produced with high overall quality and good viewing effect has more significant impact on the perception of the audience. Secondly, DMO should attach importance to UGV's representation of destination experiential content. Due to the unique experience sharing characteristics of tourists, UGV gives the destination image a unique and approachable representation effect. The analysis results of this study also show that compared with UGV, AGV is obviously insufficient in the representation of tourists' experience. Therefore, DMO needs to emphasize the analysis of UGV with greater influence, find out the "touching point" of UGV and draw lessons from it, so as to better integrate into the production of AGV. Meanwhile, making full use of the marketing communication effect of $\mathrm{UGV}$ is also a very effective marketing breakthrough way for some emerging tourism destinations, which is reflected in some internet celebrity tourism destinations emerging in recent years.

\subsection{Limitations and Future Research}

In this study, short video is taken as the research object. Due to the influence of duration of short video, in the content analysis of video representation, the number of effective samples (screenshots) used for coding is relatively small, and there may be insufficient representation of destination image elements in the video. For future studies, the number of samples of two types of video can be appropriately increased to make up for this deficiency; meanwhile, this study only focuses on the content analysis of visual representation of short video, future researches can design a questionnaires based on the grounded theory and according to the theoretical coding results of video image theme, carry out empirical research on the impact of short video on the audience's perception of destination image and behavior intention, and further explore the marketing effect of tourism short video.

\section{Acknowledgment}

The financial support for this study was provided by Anhui Philosophy and Social Science Planning Project, China (No. AHSKF2018D13)

\section{References}

[1] Crompton, J L.An assessment of the image of Mexico as a vacation destination and the influence of geographical location upon that image[J]. Journal of Travel Research,1979,17(4): 1823.

[2] Hunt J D. Image as a factor in tourism development[J]. Journal of Travel Research, 1975,13(3): 1-7.

[3] Gartner W C. Tourism image: attribute measurement of state tourism products using multidimensional scaling techniques $[\mathrm{J}]$. Journal of Travel Research, 1989,28(2): 16-20.

[4] Echtner C M,Ritchie J R B. The meaning and measurement of destination image[J]. Journal of Tourism Studies, 1991,2(2):212.

[5] Lai K, Li X R. Tourism destination image: conceptual problems and definitional solutions[J]. Journal of Travel Research, 2016,55(8):1065-1080.

[6] Beerli A, Martín J D. Factors influencing destination image[J]. Annals of Tourism Research, 2004,31(3): 657-681.

[7] Grosspietsch M. Perceived and projected images of Rwanda:visitor and international tour operator perspectives [J]. Tourism Management, 2006,27:225-234.

[8] Alvarez M D, Campo S. The influence of political conflicts on country image and intention to visit: A study of Israel's image[J]. Tourism Management, 2014,40:70-78.

[9] Kim H, Chen J S. Destination image formation process: a holistic model[J]. Journal of Vacation Marketing, 2016,22(2), 154-166.

[10] Prayag G, Hosany S, Muskat B,Chiappa G D. Understanding the relationships between tourists' emotional experiences, perceived overall image, satisfaction, and intention to recommend[J]. Journal of Travel Research,2017, 56(1):41-54.

[11] Cho, Y, Wang, Y, Fesenmaier, D R. Searching for experiences: The webbased virtual tour in tourism marketing[J]. Journal of Travel \& Tourism Marketing, 2002,12(4):1-17.

[12] Law, R, Buhalis, D, Cobanoglu, C. Progress on information and communication technologies in hospitality and tourism[J]. International Journal of Contemporary Hospitality Management, 2014,26(5):727-750. 
[13] Smith W W, Li X R, Pan B, Witte M, Doherty S T. Tracking destination image across the trip experience with smartphone technology[J]. Tourism Management, 2015, 48:113-122.

[14] Molinillo S, Liebana-Cabanillas F, Anaya-Sanchez R, Buhalis D. DMO online platforms: image and intention to visit[J]. Tourism Management,2018,65:116-130.

[15] Garrod B. Understanding the relationship between tourism destination imagery and tourist photography[J]. Journal of Travel Research, 2009,47(3):346-358.

[16] Chiou W B, Wan C S, Lee, H Y. Virtual experience vs. brochures in the advertisement of scenic spots: how cognitive preferences and order effects influence advertising effects on consumers[J]. Tourism Management, 2008, 29(1):146-150.

[17] Vries L, Gensler S,Leeflang P S. Popularity of brand posts on brand fan pages: an investigation of the effects of social media marketing[J].Journal of Interactive Marketing,2012, 26(2):8391.

[18] Alvarez M, Campo S. Controllable versus uncontrollable information sources: effects on the image of Turkey[J]. International Journal of Tourism Research, 2011, 13:310-323.

[19] Kim S, Choe J Y, Lee S. How are food value video clips effective in promoting food tourism? Generation $Y$ versus nonGeneration Y[J].Journal of Travel \& Tourism Marketing, 2018,35(3): 377-393.

[20] Reino S, Hay B. The use of YouTube as a tourism marketing tool[R]. Travel and Tourism Research Association: Advancing Tourism Research Globally, 2011, 69.

[21] Lim Y, Chung Y, Weaver P A. The impact of social media on destination branding: consumer-generated videos versus destination marketer-generated videos[J]. Journal of Vacation Marketing, 2012,18(3): 197-206.

[22] Losada N, Mota G. 'Slow down, your movie is too fast': slow tourism representations in the promotional videos of the Douro region(Northern Portugal)[J]. Journal of Destination Marketing \& Management,2019,11:140-149.

[23] Connell, J. Toddlers, tourism, and Tobermory: destination marketing issues and television-induced tourism[J]. Tourism Management, 2005, 26(5):763-776.

[24] Stepchenkova, Zhan F. Visual destination images of Peru: Comparative content analysis of DMO and user-generated photography[J]. Tourism Management, 2013,36:590-601.

[25] Gallarza, M G, Saura, I G, García, H C. Destination image: Towards a conceptual framework[J]. Annals of Tourism Research, 2002, 29(1):56-78.

[26] Baloglu S, McCleary K W. A model of destination image formation[J]. Annals of Tourism Research, 1999, 26(4):868897.

[27] Kim H, Richardson S L. Motion picture impacts on destination images[J]. Annals of Tourism Research,2003,30(1):216-37.

[28] Walmsley D J, Young M. Evaluative images and tourism: the use of personal constructs to describe the structure of destination images[J]. Journal of Travel Research,1998,36: 6569.

[29] Prayag G, Ryan C. Antecedents of tourists' loyalty to Mauritius: the role and influence of destination image, place attachment, personal involvement, and satisfaction[J]. Journal of Travel Research,2012,51(3):342-356.

[30] Veasna S, Wu W Y, Huang CH. The impact of destination source credibility on destination satisfaction: the mediating effects of destination attachment and destination image[J]. Tourism Management, 2013, 36:511-526.
[31] Ahmed Z U. The influence of the components of a state's tourist image on product positioning strategy[J]. Tourism Management, 1991,12(4):331-340.

[32] Woodside A G, Lysonski S. A general model of traveler destination choice[J]. Journal of Travel Research, 1989, 27(4): 8-14.

[33] Choi J G, Tkachenko T, Sil S. On the destination image of Korea by Russian tourists[J]. Tourism Management,2011, 32:193-194.

[34] Chi C G, Qu H. Examining the structural relationships of destination image, tourist satisfaction and destination loyalty: an integrated approach[J]. Tourism Management,2008,29:624-636.

[35] Yüksel A, Akgül O. Postcards as affective image makers: an idle agent in destination marketing[J]. Tourism Management, 2007, 28(3):714-725.

[36] Jenkins O H. Photography and travel brochures: the circle of representation[J]. Tourism Geographies, 2003, 5(3):305-328.

[37] Pan S, Lee J, Tsai H. Travel photos: motivations, image dimensions, and affective qualities of places[J]. Tourism Management, 2014,40:59-69.

[38] Pearce PL, Wu M Y, Chen T. The spectacular and the mundane Chinese tourists' online representations of an iconic landscape journey[J]. Journal of Destination Marketing \& Management,2015, 4: 24-35.

[39] Sun M, Ryan C, Pan S. Assessing tourists' perceptions and behavior through photographic and blog analysis: the case of Chinese bloggers and New Zealand holidays[J]. Tourism Management Perspectives, 2014,12:125-133.

[40] Michaelidou N, Siamagka N T, Moraes C,Micevski M. Do marketers use visual representations of destinations that touristsvalue?Comparing visitors' image of a destination with marketer-controlled images online[J]. Journal of Travel Research, 2013,52(6):789-804.

[41] Syed-Ahmad S F, Musa G, Klobas J E, Murphy J. Audience response to travel photos and Arab destination image[J]. Journal of Travel \& Tourism Marketing,2013,30:161-164.

[42] Shani A, Chen P J, Wang Y, Hua N. Testing the impact of a promotional video on destination image change: application of China as a tourism destination[J]. International Journal of Tourism Research, 2010,12:116-133.

[43] Pan S. The role of TV commercial visuals in forming memorable and impressive destination images[J]. Journal of Travel Research, 2011,50(2):171-185.

[44] Cheng D N, Zhou Y B, Wei X D. A structure comparison between tourism short films and promos based on content analysis[J]. Tourism Tribune, 2015,30(10):109-122(in Chinese).

[45] Hautz J, Füller J, Hutter K, Thürridl C. Let users generate your video ads? The impact of video source and quality on consumers' perceptions and intended behaviors[J]. Journal of Interactive Marketing, 2014,28: 1-15.

[46] Alamäki A, Pesonen J, Dirin A. Triggering eects of mobile video marketing in nature tourism: media richness perspective[J]. Information Processing and Management, 2019, 56:756-770.

[47] Holsti O R. Content analysisforthe social sciencesand humanities[M]. Addison-Wesley Pub. Co. p. ,1969, 137-141.

[48] Stemler S. An overview of content analysis[J].Practical Assessment, Research, and Evaluation, 2001,7:1-6.

[49] Agustí D P. Characterizing the location of tourist images in cities. differences in user-generated images (Instagram), 
official tourist brochures and travel guides[J]. Annals of Tourism Research, 2018,73:103-115.
[50] Deng N, Liu J Y, Dai Y, Li H. Dierent cultures, dierent photos: a comparison of Shanghai's pictorial destination image between East and West[J]. Tourism Management Perspectives, 2019,30:182-192. 